\title{
Reliability and Validity of the Spielberger's State-Trait Anxiety Inventory (STAI) in Serbian University Student and Psychiatric Non-Psychotic Outpatient Populations
}

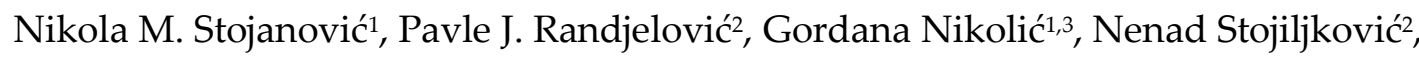 \\ Sonja Ilić́ ${ }^{2}$, Bogdan Stoiljković ${ }^{1}$ Niko S. Radulović ${ }^{4}$ \\ ${ }^{1}$ University of Niš, Faculty of Medicine, Niš, Serbia \\ ${ }^{2}$ University of Niš, Faculty of Medicine, Department of Physiology Niš, Serbia \\ ${ }^{3}$ Center for Mental Health, Clinical Center Niš, Niš, Serbia \\ ${ }^{4}$ University of Niš, Faculty of Sciences and Mathematics, Department of Chemistry, Niš, Serbia
}

\section{SUMMARY}

Anxiety is an inborn emotional and cognitive reaction that enables humans to cope with everyday situations, however, it can be pathological as well. Although Spielberger's State-Trait Anxiety Inventory (STAI) scales are most frequently used to study the presence/absence of anxiety, there is a lack of empirical studies in Serbian healthy and/or diseased population that would indicate its reliability and validity. The aim of the present study was to determine some normative values for STAI scales (state and trait) and to determine its reliability and validity in the studied population of university students and psychiatric patients. Score values obtained from the two analyzed samples, which did not show a normal distribution, showed to be statistically significantly different. Receiver operating characteristic curve analysis revealed that values of area under the curve for the two scales were $>0.85(\mathrm{p}<0.001)$ and cut-off values suggested that the presence of anxiety was determined to be 38.5 for the S-scale and 45.5 for the T-scale. Data analysis revealed, according to the intraclass correlation coefficient, that S-scale had a moderate reliability (Cronbach alpha $=0.713$ ) and that T-scale had a good reliability (Cronbach alpha $=0.858)$. Also, STAI scales given to patients suffering from anxiety disorders were determined to measure the presence of anxiety with coefficient alpha higher than 0.9 . The calculated validity, internal consistency, and reliability for the translated STAI version are satisfactory, meaning that the usage of the translated STAI can clearly measure the changes in the level of anxiety in patients suffering from neurotic, stress-related, and somatoform disorders.

Key words: STAI scales, anxiety, validity, reliability

Corresponding author:

Nikola M. Stojanović

E-mail: nikola.st90@yahoo.com 


\section{INTRODUCTION}

Anxiety is an inborn emotional and cognitive reaction that enables humans to cope with everyday situations. There are two almost clear entities in anxiety, i.e. a physiological and a pathological one, however, the two entities could sometimes be quite indistinct (1). The 10th international classification of diseases (ICD-10) defines four large subgroups of anxiety disorders which include phobic anxious disorders, other types of anxiety disorders, obsessive-compulsive disorders and the reaction to severe stress and accommodation disorders. The ICD-10 in its recommendations elaborates on different parameters, somatic and psyche-related ones, which need to be assessed in order to meet the correct diagnosis (2).

Spielberger's State-Trait Anxiety Inventory (STAI) was constructed by Spielberger in the 1970s (3) and since then, although revised, it is widely used for the estimation of anxiety levels both in research and everyday clinical practice. It consists of two separate self-report scales that allow the estimation of two distinct anxiety concepts, i.e. state(S-) and trait-anxiety (T-anxiety). "State anxiety is conceptualized as a transitory emotional state or condition that is characterized by subjective, consciously perceived feelings of tension and apprehension and heightened autonomic nervous system activity" is the definition of S-anxiety (3), whereas the T-anxiety" refers to relatively stable individual differences in anxiety proneness that is due to differences between people with the tendency to respond to situations perceived as threatening with elevations in state anxiety intensity" (3). The STAI is comprised of 40 questions. The S-anxiety scale consists of 20 statements to indicate how the respondents feel at a particular moment in time, while the T-anxiety scale consists of 20 statements through which the respondents describe how they generally feel. The clear difference between the results obtained by these two scales, the concept that S- and T-anxieties are different, has been previously proven on several occasions (4). In a group of hospitalized patients suffering from anxiety disorders, the stressful interview caused an increase in the S-scale scores, followed by the arousal of the autonomic nervous system, but not in the T-scale scores (4).

In psychological/psychiatric studies it is not sufficient to just select an instrument (scale) that will be used in order to measure the studied feature. The selected scale needs to be validated, i.e. to measure the exact feature that is investigated and to be reliable, i.e. to measure the studied change precisely. Thus, it is of vast importance to have the instrument validated and its reliability estimated prior to its usage in experiments. Although STAI scale is extensively used, up to now there have been only a few publications that dealt with its reliability and validity in the ex-Yugoslavia population $(5,6)$ and the norms for STAI still do not exist for the Serbian population (5).

Having all previously mentioned facts in mind, this study aims to estimate the reliability and validity, as well as some norms, of STAI in a randomly selected population of second-year medical students and patients suffering from anxiety disorders from Serbia.

\section{PARTICIPANTS AND METHODS}

\section{Study population}

Subjects included in this study were Caucasian young healthy second-year medical students ( $\mathrm{n}$ $=156$; males $=50$; females $=106$ ), with an average age of 20.4 years, and outpatients $(n=129$; males $=52$; females $=77$ ) suffering from neurotic, stress-related and somatoform disorders (F40-48), with an average age of 37.8 years. Prior to the study, the subjects were informed about the nature of the study and they all gave their informed consent for the enrolment in the study. The students were selected by random sampling and their participation was voluntary and anonymous. Students, present at the practical course at the department of physiology, were selected based on a coin roll. Patients suffering from neurotic, stress-related, and somatoform disorders that were enrolled in the study were selected based on the method of consecutive admissions. The study was previously approved by the Ethics committee of the Faculty of Medicine, University of Niš and Clinical Center Niš, and was conducted in accordance with the Declaration of Helsinki.

\section{Procedure}

Initial examination of healthy students was performed during the first week of the practical course at the Department of Physiology, Faculty of Medicine, University of Niš, while the second ex- 
amination was performed one week later. The examinations were performed between $11 \mathrm{AM}$ and 1 PM; each subject was given a printed questionnaire comprised of S- (state) and T- (trait) scales and were supervised by trained researchers (N.M.S. and/or B.S.).

Patients suffering from an anxiety disorder were tested only once, during their first visit to a psychiatrist at the Center for Mental Health, Clinical Center Niš. The examinations were performed between 9 AM and 1 PM; each subject was given a printed questionnaire comprised of S- and T-scales and their examination was supervised by a psychiatrist (G.N.).

\section{Instrument}

A 4-point Likert scale measured the intensity of these dimensions: one (not true) to four (true). In the case of the S-scale, the subjects were instructed to rate their present anxiety state (right now) in the scale ranging from "not at all" to "very much so", while in the case of the T-scale, the subjects were instructed to rate their constant anxiety state (general feeling) in the scale from "almost never" to "almost always" (7). The score values for S- and T-scales, scored as directed in the manual, were obtained by adding the Likert scale points for each of the 20 questions from S- and T-scales. Each of two THE scales contained two factors, which Spielberger labeled as anxiety present and anxiety-absent factors (7). The hypothetical minimal score for S- or T-scales was 20, and the maximal hypothetical score was 80 . The prorating procedure was employed when the subject did not answer the question; it was determined as a mean value of score for the items that the subject responded to, multiplied by 20 (8). The scale was translated from English to Serbian and then back-translated into English.

\section{Statistical analysis}

Score values obtained from S- and T-scales were analyzed using GraphPad Prism (version 5.03, San Diego, CA, USA) and SPSS (version 21.0, IBM Corp, 2012). Prior to the comparison of the mean values for S- and T-scales obtained from diseased and non-diseased subjects, the normality of the data was tested using the Shapiro-Wilk test. The data are presented as the median and interquartile ranges
(IQR), as well as the minimal and maximal values calculated for each of the scales. The percent of prorated values was also included as a part of the descriptive statistics. A comparison between the mean rank values was performed using the MannWhitney $U$ Test, and the obtained results are given as $\mathrm{Z}$ and $\mathrm{p}$-values.

The validity of both scales (S- and T-scales) was determined using the receiver operating characteristic (ROC) curve analysis and was performed using the final scores obtained from healthy (non-diseased) and diseased subjects. The results of this analysis are presented as the area under the curve (AUC), 95\% confident intervals (C.I.) and probability values (p) (9). Cut-off values with the optimal balance between sensitivity and specificity were determined by visually assessing the ROC curves. For each cut-off value, we computed sensitivity (true-positive rate), specificity (truenegative rate) and calculated $95 \%$ C.I. for each value of sensitivity and specificity.

The intraclass correlation coefficient (ICC) and their $95 \%$ C.I. for the total scores obtained from healthy subjects at first and second examinations were calculated based on absolute agreement, twoway mixed-effects model as suggested for this type of studies (10). Also, the coefficient (Cronbach's) alpha as a measure of consistency, for the results obtained from the diseased group of subjects, was calculated for the two factors found in each scale.

\section{RESULTS AND DISCUSSION}

The descriptive statistical data relating to the scores obtained from the S- and T-scales collected in the sample of non-diseased $(n=156)$ and diseased $(\mathrm{n}=129)$ subjects are given in Table 1 . There was no overlap between the prorated scores, meaning that the same subject did not leave the question unanswered in two scales, given on two occasions (in the case of the non-diseased subjects) (Table 1). In total, male score values had to be prorated much less than the ones obtained from females, which is in accordance with previous publications (8). The median values obtained for the S- and T-scales on the first and second tests were very similar. Such finding is not surprising for the T-scale since this scale represents a more general/continuous state of mind. However, the results for the S-scale are a bit unexpected if one has in mind that this scale estimates the current anxiety state. These results 
Table 1. Descriptive statistics parameters obtained from the $S$ - and T-scales

\begin{tabular}{|c|c|c|c|c|c|c|}
\hline \multirow{2}{*}{ Study group } & \multirow{2}{*}{\multicolumn{2}{|c|}{ STAI scale parameters }} & \multicolumn{2}{|c|}{ First test } & \multicolumn{2}{|c|}{ Second test } \\
\hline & & & Male & Female & Male & Female \\
\hline \multirow{11}{*}{$\begin{array}{l}\text { Non-diseased } \\
\qquad(\mathrm{n}=156)\end{array}$} & S-scale & Median & 32 & 34 & 33 & 36 \\
\hline & & IQR & $28-39$ & $31-40$ & $30-39$ & $31-41$ \\
\hline & & $\operatorname{Max}$ & 60 & 62 & 53 & 59 \\
\hline & & Min & 20 & 22 & 20 & 20 \\
\hline & & Prorated values (\%) & 1.92 & 1.92 & 2.6 & 0.6 \\
\hline & & & & & & \\
\hline & T-scale & Median & 36 & 37 & 34 & 34 \\
\hline & & IQR & $33-38$ & $34-42$ & $29-37$ & $30-43$ \\
\hline & & Max & 52 & 68 & 51 & 67 \\
\hline & & Min & 20 & 21 & 20 & 20 \\
\hline & & Prorated values (\%) & 0.6 & 7.1 & 1.2 & 3.9 \\
\hline \multirow{11}{*}{$\begin{array}{l}\text { Diseased } \\
(\mathrm{n}=129)\end{array}$} & S-scale & Median & 56 & 56 & 1 & 1 \\
\hline & & IQR & $48-66$ & $41-65$ & 1 & 1 \\
\hline & & Max & 77 & 76 & 1 & 1 \\
\hline & & Min & 30 & 23 & 1 & 1 \\
\hline & & Prorated values (\%) & 2.3 & 3.1 & 1 & 1 \\
\hline & & & & & & \\
\hline & T-scale & Median & 56 & 55 & 1 & 1 \\
\hline & & IQR & $47-61$ & $48-61$ & 1 & 1 \\
\hline & & Max & 69 & 79 & 1 & 1 \\
\hline & & Min & 20 & 32 & 1 & 1 \\
\hline & & Prorated values (\%) & 3.9 & 4.6 & 1 & 1 \\
\hline
\end{tabular}

could be explained by the fact that the tests are given to healthy (non-diseased) students on the day of their initial and second practical course lessons, which might be considered as a mild anxiety-inducing situation for the majority of students. Also, the University students are known to experience some difficulties while adapting to the new academic environment, different types of academic commitments, self-management, time management, interpersonal relationships, and financial management (11). Thus, it is not surprising that anxiety is among the most common disorders in the student population (11). Additionally, S-Anxiety validity was originally derived from testing in situations characterized by a high state of stress including classroom examinations, military training programs, etc. (12). Interestingly, similar mean, maximal and minimal values for STAI scales were obtained from healthy male professional basketball players originating from Serbia (13).
In the case of the patient group, high S- and Tscale scores are completely expected since these subjects came to a psychiatrist seeking help, and accordingly, their scores were notably higher (Table 1). In clinical settings, the S-scale can be of great value since it was suggested to be an indicator of changes in the anxiety levels that result from therapy (14). Another notable difference between the studied groups of subjects is the maximal value for both scales, especially the S-scale (Table 1). In the group of non-diseased subjects, we did not find a ceiling effect (extreme value), however, in the group of diseased subjects (patients), this effect was clearly notable. Such high maximal values could possibly be the patient real state (true anxiety) or he/she responded according to what one thinks the interviewer would expect, i.e. the case of the Rosenthal effect (15).

Frequency distribution analysis for both scale scores obtained from both healthy and diseased sub- 
jects did not point to the normal distribution (Figure 1 and 2), where the Shapiro-Wilk test revealed the $p$ value to be $<0.001$ in for all scales. In the studies that were designed to collect the data (variables) from instruments assessing the health status of an individual, one can often encounter an asymmetric distribution of variables within the sample (16). The majority of the healthy individuals were positioned at the beginning of the graph, while the minority of the healthy individuals were positioned at the far right side, thus showing a characteristic long-tailed distribution (Figure 1). On the other hand, the group of diseased subjects should be mainly distributed at the far end of the distribution (Figure 2). Our sample did not display this kind of distribution (i.e. not a "perfect" distribution), however, one should have in mind that the nature of the instruments, subject population and the type of measure could influence the outcome of such an analysis. In this particular case, the instrument is designed to measure a personal opinion related to its psyche, which should not be regarded as non-bias, and, thus, the results might not appear to be ideal.

Since a non-normal distribution of data was found (Figures 1 and 2), the comparison between the $\mathrm{S}$ - and T-scale scores obtained initially for the nondiseased and diseased subjects of different genders was done using the Mann-Whitney U Test (Table 2). The results showed significantly higher S-score values for the non-diseased females compared to the males, while such a difference was not observed in the diseased subject group (Table 2). On the other hand, a significantly higher mean rank value for the $\mathrm{T}$-scale was found in the female patients compared to the males (Table 2). A similar statistically significant increase in healthy female subjects' $S$ anxiety levels was previously found among the Norwegian conservatory music students (17). Also, since the T-scale scores were found to be significantly higher in the diseased females, this suggests that females have more proneness for anxiety-related disorders. Gender differences analy-
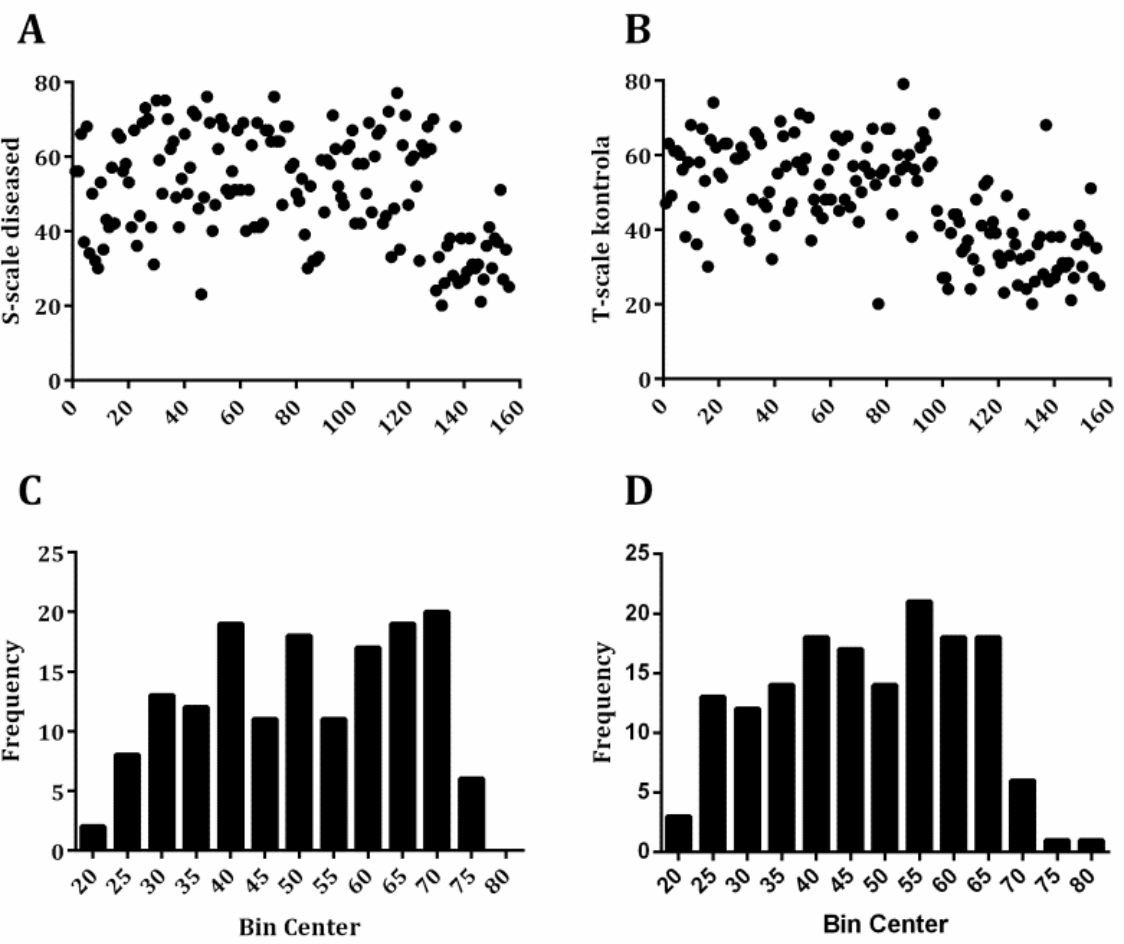

Figure 1. Frequency distribution of the data from the $S$-scale (part $A$ and $C$ ) and the $T$-scale (part $B$ and $D$ ) obtained from non-diseased subjects on the first test 
A

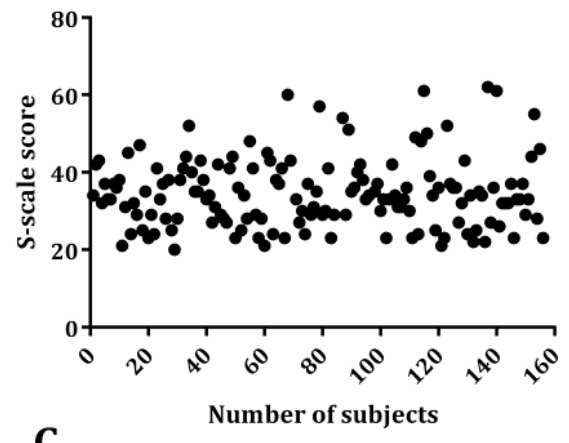

C

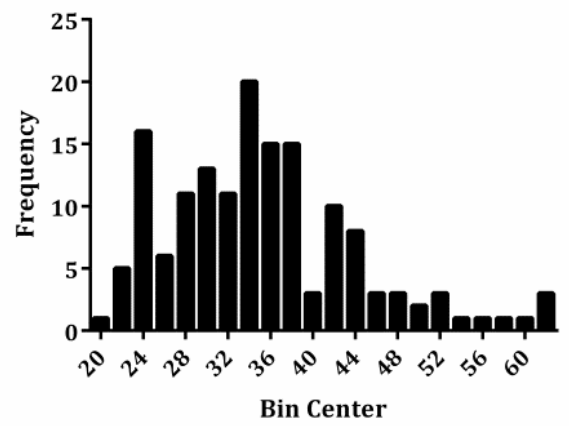

B

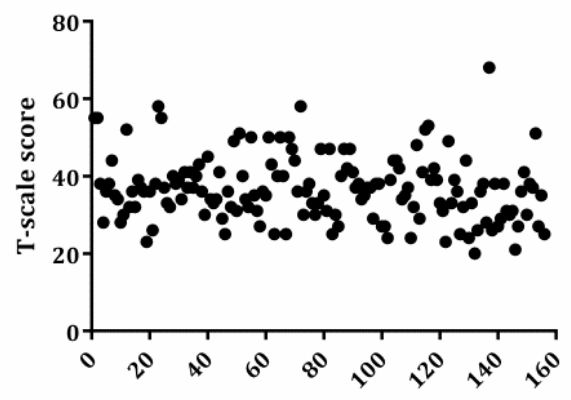

D Number of subjects

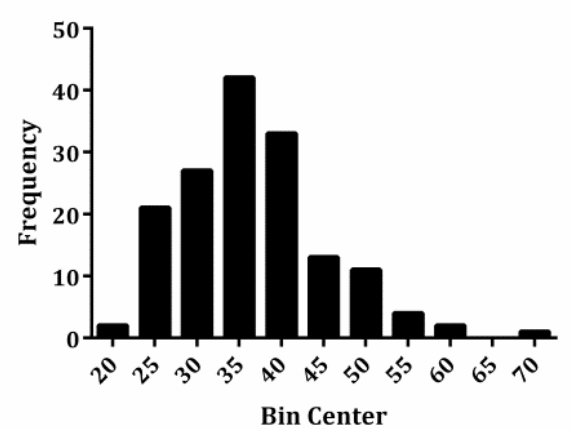

Figure 2. Frequency distribution of the data from the $S$-scale (part $A$ and $C$ ) and the $T$-scale (part $B$ and $D$ ) obtained from diseased subjects

Table 2. Gender differences between mean rank values for different genders obtained from the $S$ - and T-scales

\begin{tabular}{|c|c|c|c|c|c|c|c|}
\hline $\begin{array}{l}\text { Type of } \\
\text { scale }\end{array}$ & & $\begin{array}{c}\text { Non- } \\
\text { diseased }\end{array}$ & $\begin{array}{c}\text { Number of } \\
\text { subjects }\end{array}$ & $\mathrm{Z}, p$-value & Diseased & $\begin{array}{c}\text { Number of } \\
\text { subjects }\end{array}$ & $\mathrm{Z}, p$-value \\
\hline \multirow{3}{*}{ S-scale } & Total & 90.88 & 156 & & 200.06 & 129 & $-11.228,<0.001$ \\
\hline & Male & 66.26 & 50 & \multirow{2}{*}{$-1.981,0.048$} & 62.35 & 52 & \multirow{2}{*}{$-0.663,0.507$} \\
\hline & Female & 81.37 & 106 & & 66.79 & 77 & \\
\hline \multirow{3}{*}{ T-scale } & Total & 92.23 & 156 & & 204.4 & 129 & $-11.440,<0.001$ \\
\hline & Male & 72.41 & 50 & \multirow{2}{*}{$-1.158,0.247$} & 55.98 & 52 & \multirow{2}{*}{$-2.253,0.024$} \\
\hline & Female & 81.37 & 106 & & 71.09 & 77 & \\
\hline
\end{tabular}

sis that encompassed more than 20.000 patients revealed that females diagnosed with an anxiety disorder more frequently had another anxiety disorder, bulimia nervosa, and/or major depressive disorder (18). An additional important finding of the analysis is that the S- and T-scale scores obtained for healthy and diseased subjects mutually differed (Table 2), thus confirming the adequacy of the two studied groups.

Statistical analysis performed in order to esti- mate the validity of S- and T-scales, i. e. ROC curve analysis, revealed that the values of AUC for the two scales are $>0.85(p<0.001$; Table 3, Figure 3). The values of the AUC indicate the chance that the diseased subject will be classified correctly (as diseased), by either the S- or T-scale, rather than a randomly chosen non-diseased subject (9). Our data suggest, with statistical significance $(p<0.001)$, that in $88 \%$ of the tested subjects, the scales will detect true anxiety, rather than classifying the subject as 
Table 3. Results for ROC curves obtained for the S- and T-scales

\begin{tabular}{|c|c|c|c|}
\hline \multicolumn{2}{|c|}{ ROC curve descriptors } & \multicolumn{2}{|c|}{ Scale } \\
\hline & & $S$ & $\mathrm{~T}$ \\
\hline \multirow[t]{5}{*}{ AUC } & Value & $0.886 \pm 0.0195$ & $0.893 \pm 0.0195$ \\
\hline & 95\% C.I. & & \\
\hline & Lower bound & 0.851 & 0.855 \\
\hline & Upper bound & 0.927 & 0.931 \\
\hline & $\mathrm{p}$ value & $<0.001$ & $<0.001$ \\
\hline Cut-off value & & $>38.5$ & $>45.5$ \\
\hline \multirow[t]{4}{*}{ Sensitivity } & Percent (\%) & 88.37 & 78.29 \\
\hline & 95\% C.I. & & \\
\hline & Lower bound & 81.55 & 70.18 \\
\hline & Upper bound & 93.34 & 85.07 \\
\hline \multirow[t]{4}{*}{ Specificity } & Percent (\%) & 73.68 & 86.54 \\
\hline & 95\% C.I. & & \\
\hline & Lower bound & 65.93 & 80.16 \\
\hline & Upper bound & 80.49 & 91.47 \\
\hline
\end{tabular}

A

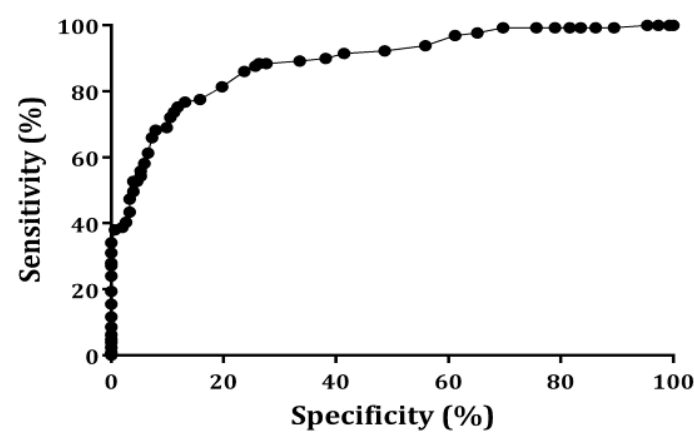

B

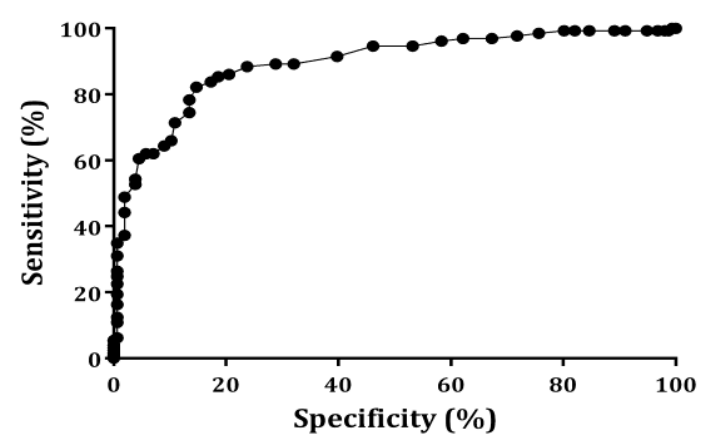

Figure 3. ROC curve derived from the two overlapping distributions, (A) S-scale STAI and (B) T-scale STAI

Table 4. Results for ICC obtained for the S- and T-scales from SPSS based on the absolute-agreement in a two-way mixed-effects model

\begin{tabular}{cccccccc}
\hline \hline \multirow{2}{*}{ Scale } & \multirow{2}{*}{ ICC } & \multicolumn{3}{c}{$95 \%$ C.I. } & \multicolumn{3}{c}{ F test with true value 0 } \\
\cline { 3 - 8 } & & Lower bound & Upper bound & Value & $d f 1$ & $p$ \\
\cline { 3 - 8 } $\mathrm{S}$ & \multirow{2}{*}{ Average measurement } & 0.713 & 0.613 & 0.796 & 3.562 & 151 & $<0.001$ \\
$\mathrm{~T}$ & 0.858 & 0.795 & 0.901 & 7.018 & 116 & $<0.001$ \\
\hline \hline
\end{tabular}


healthy. Similar values for AUC in STAI were previously determined in Lithuanian (19), Australian (8) and other populations. Such findings are important and the validity determination must be performed in each studied population since the data from the manual are obtained from quite specific/narrow populations of either high school students or male psychiatric patients (8).

Besides the mentioned interpretation, the ROC curve analysis allowed us to determine the optimal cut-off values for the test that we applied $(20,9)$. The determined cut-off values for the $\mathrm{S}$ - and T-scales were found to be 38.5 and 45.5, respectively (Table $3)$, which is close to the suggested cut-off values, 39/40, for STAI (21). STAI is widely used for the estimation of anxiety levels in various patient populations (e.g. cardiovascular disorders, pregnant women) hence the cut-off values could significantly vary $(22,19)$.

The obtained value for ICC indicates a moderate reliability for the S-scale and a good reliability for the T-scale of the State-Trait Inventory (Table 4). The reliability of each of the scales was interpreted based on previous studies that were using not only ICC values but $95 \%$ C.I. as well (10). Lower ICC and 95\% C.I. values were found for the S-scale compared to those of the T-scale, and these were not unexpected if one has the nature of the constructed questionnaire in mind. Namely, the S-scale is designed to determine the present state of anxiety and is significantly more prone to the changes that could occur within minutes (seconds). On the other hand, the T-scale determines how someone "generally feels", or, to be more precise, how did the previous state-anxiety experience affect its general anxiety (23). On the other hand, one cannot neglect that this test-retest study was performed on healthy university students, which might be exposed to different stress intensity, as previously mentioned.

The reliability data (Table 4) suggest that the STAI scale applied to diseased subjects measures the presence of anxiety with the coefficient alpha higher than 0.9. Similar values were obtained for the coefficient alpha, 0.93 for the S-scale and 0.87 for the T-scale, in other studied populations (8). We have not found any negative correlations between the items of either of the scales. The corrected item-total correlation was calculated to be relatively high, and if the selected item would be deleted, the coefficient alpha would not change drastically. Thus, the translated into Serbian STAI, S- and T-scales, consisting of 20 questions each could be used with high reliability for the estimation of anxiety.

\section{CONCLUSIONS}

The present study revealed that translated into Serbian STAI scales in the studied population have good psychometric properties that are comparable with the findings of the English STAI version. The calculated validity, internal consistency, and reliability for the translated STAI version are satisfactory, meaning that the usage of the translated STAI can clearly measure the changes in the level of anxiety in patients suffering from neurotic, stressrelated and somatoform disorders.

\section{Acknowledgment}

This work was funded by the Ministry of Education, Science and Technological Development of the Republic of Serbia, Grant No. 172061. 


\section{References}

1. Stojanović MN, Nikolić G, Todorovska M, et al. Anxiety Disorders - Where do we stand now Current medicamentous treatment knowledge and future perspectives. Acta Fac Med Naiss 2019; 36(2):91-101.

https://scindeks-clanci.ceon.rs/data/pdf/03516083/2019/0351-60831902091S.pdf

2. Barton S, Karner C, Salih F, et al. Clinical effectiveness of interventions for treatmentresistant anxiety in older people: a systematic review. Health Technol Assess 2014; 18(50):1-59. https://doi.org/10.3310/hta18500

3. Spielberger CD, Gorsuch RL, Lushene RE. STAI: manual for the State-Trait Anxiety Inventory. Palo Alto: Consulting Psychologists; 1970

4. Johnson DT. Effects of interview stress on measures of state and trait anxiety. J Abnorm Psychol, 1968; 73(3):245-51.

https://doi.org/10.1037/h0025860

5. Popov B. Contribution to assessment of effects of Rational emotive behaviour therapy. Psihologija 2004; 37(3):375-88.

https://doi.org/10.2298/PSI0403375P

6. Berberovic D. Sexual compulsivity comorbidity with depression, anxiety, and substance use in students from Serbia and Bosnia and Herzegovina. Eur J Psycho, 2013; 9(3): 517-30. https://doi.org/10.5964/ejop.v9i3.595

7. Spielberger CD. State-Trait Anxiety Inventory. A comprehensive bibliography. Palo Alto, CA: Consulting Psychologists Press. 1983.

8. Knight RG, Waal-Manning HJ, Spears GF. Some norms and reliability data for the State-Trait
Anxiety Inventory and the Zung Self-Rating Depression scale. Br J Clin Psychol 1983; 22 (Pt 4):245-49.

https://doi.org/10.1111/j.2044-8260.1983.tb00610.x

9. Hajian-Tilaki K. Receiver operating characteristic (ROC) curve analysis for medical diagnostic test evaluation. Caspian J Intern Med 2013; 4(2):62735.

https://www.ncbi.nlm.nih.gov/pmc/articles/PMC3 755824/pdf/cjim-4-627.pdf

10. Koo TK, Li MY, A Guideline of selecting and reporting intraclass correlation coefficients for reliability research. J Chiropr Med 2016; 15(2):15563.

https://doi.org/10.1016/j.jcm.2016.02.012

11. Seok CB, Hamid HSA, Mutang JA, et al. Psychometric properties of the state-trait anxiety inventory (form Y) among Malaysian university students. Sustainability 2018; 10(9): 1-13. https://www.mdpi.com/2071-1050/10/9/3311/pdf

12. Julian LJ. Measures of anxiety: State-Trait Anxiety Inventory (STAI), Beck Anxiety Inventory BAI), and Hospital Anxiety and Depression ScaleAnxiety (HADS-A). Arthritis Care Res (Hoboken), 2011; 63 Suppl 11:S467-72. https://doi.org/10.1002/acr.20561

13. Jakovljević S, Karalejić M, Lazarević Lj. The latent structure of conative dimensions of Elite senior and junior basketball players. FU Phys Ed Sport 2010; 8(1):21-30.

14. Metzger RL. (1976). A reliability and validity study of the State-Trait Anxiety Inventory. J Clin Psychol1976; 32(2): 276-8.

https://doi.org/10.1002/1097-4679(197604)32:2<276 
15. Rosenthal R. Pygmalion effects: Existence, magnitude, and social importance. Educat Res1987; 16(9): 37-40.

https://doi.org/10.3102/0013189X016009037

16. Counsell N, Cortina-Borja M, Lehtonen A, Stein A. Modelling psychiatric measures using SkewNormal distributions. Eur Psychiatry 2011; 26(2):112-4.

https://doi.org/10.1016/j.eurpsy.2010.08.006

17. Kaspersen M, Götestam KG. A survey of music performance anxiety among Norwegian music students. Eur J Psychiatry 2002; 16(2):69-80.

18. McLean CP, Asnaani A, Litz BT, Hofmann SG. Gender differences in anxiety disorders: prevalence, course of illness, comorbidity and burden of illness. J Psychiatr Res 2011; 45(8):1027-35.

https://doi.org/10.1016/j.jpsychires.2011.03.006

19. Bunevicius A, Staniute M, Brozaitiene J, et al. Screening for anxiety disorders in patients with coronary artery disease. Health Qual Life Outcomes 2013; 11:37. https://doi.org/10.1186/1477-7525-11-37
20. Kummar R, Indrayan A. Receiver operating characteristic (ROC) curve for medical researchers. Indian Pediatr 2011; 48:277-489. https://doi.org/10.1007/s13312-011-0055-4

21. Kristiansen IS, Gyrd-Hansen D, Nexøe J, et al. Number needed to treat: easily understood and intuitively meaningful? Theoretical considerations and randomized trial. J Clin Epidemiol 2002; 55: 888-92.

https://doi.org/10.1016/S0895-4356(02)00432-8

22. Grant KA, McMahon C, Austin MP. Maternal anxiety during the transition to parenthood: a prospective study. J Affect Disord 2008, 108:10111.

https://doi.org/10.1016/i.jad.2007.10.002

23. Grös DF, Antony MM, Simms LJ, et al. Psychometric properties of the State-Trait Inventory for Cognitive and Somatic Anxiety (STICSA): comparison to the State-Trait Anxiety Inventory (STAI). Psychol Assess 2007; 19(4):36981.

https://doi.org/10.1037/1040-3590.19.4.369 


\title{
Pouzdanost i validnost upitnika Spilbergerovih skala anksioznosti ispitivane u populaciji studenata i nepsihotičnih psihijatrijskih ambulantnih bolesnika iz Srbije
}

\author{
Nikola M. Stojanović1, Pavle J. Randjelović́2, Gordana Nikolić1,3, Nenad Stojiljković2, Sonja Ilić2 \\ Bogdan Stoiljković ${ }^{1}$ Niko S. Radulović ${ }^{4}$ \\ ${ }^{1}$ Univerzitet u Nišu, Medicinski fakultet, Niš, Srbija \\ ${ }^{2}$ Univerzitet u Nišu, Medicinski fakultet, Institut za fiziologiju, Niš, Srbija \\ ${ }^{3}$ Zavod za mentalno zdravlje, Klinički centar Niš, Niš, Srbija \\ ${ }^{4}$ Univerzitet u Nišu, Prirodno-matematički fakultet, Departman za hemiju, Niš, Srbija
}

\begin{abstract}
SAŽETAK
Anksioznost je urođena emocionalna i kognitivna reakcija koja čoveku omogućava da se izbori sa svakodnevnim situacijama. Međutim, anksioznost može biti i patološki odgovor. Iako se upitnik Spilbergerovih skala anksioznosti (STAI) najčešće koristi $u$ ispitivanju prisustva/odsustva anksioznosti, ne postoji dovoljan broj istraživanja sprovedenih na zdravom i/ili bolesnom stanovništvu Srbije, koja bi ukazala na pouzdanost i validnost ovog testa. Stoga je cilj ovog istraživanja bilo utvrđivanje normativnih vrednosti STAI skala (stanje $i$ crta) $i$ utvrđivanje njihove pouzdanosti $i$ validnosti $u$ ispitivanim grupama univerzitetskih studenata i nepsihotičnih psihijatrijskih bolesnika. Vrednosti dobijene iz dva uzorka, koje nisu pokazivale normalnu distribuciju, bile su statistički značajno različite. Analiza Receiver Operating Characteristic krive otkrila je da su vrednosti površine ispod krive (AUC) za obe skale bile $>0,85$, pri p < 0,001, a izračunate granične vrednosti za prisustvo anksioznosti iznosile su 38,5 za $S$ skalu, odnosno 45,5 za $\mathrm{T}$ skalu. Dodatna analiza podataka pokazuje to da, prema koeficijentu intraklasne korelacije, $\mathrm{S}$ skala ima umerenu pouzdanost (Kronbah $\alpha=0,713$ ), a da T skala ima dobru pouzdanost (Kronbah $\alpha=0,858$ ). Takođe, Spilbergerove skale anksioznosti (STAI), za bolesnike koji pate od anksioznih poremećaja, ukazuju na prisustvo anksioznosti sa vrednostima koeficijenta alfa većim od 0,9 . Izračunate validnost, interna doslednost i pouzdanost STAI skala, prevedene na srpski su zadovoljavajuće, što znači da se korišćenjem prevedenih STAI skala mogu jasno utvrditi promene u stepenu anksioznosti kod bolesnika koji pate od neurotskih poremećaja, poremećaja izazvanih stresom i somatoformnih poremećaja.
\end{abstract}

Ključne reči: STAI skale, anksioznost, validnost, pouzdanost 